\title{
Distribution and phylogeny of Mycosisymbrium cirrhosum
}

\author{
Pratibha $\mathbf{J}^{1}$ and Prabhugaonkar $\mathrm{A}^{2}$ \\ ${ }^{1 *}$ Department of Botany, Goa University, Goa 403206, India. Email: jalmipratibha@ rediffmail.com \\ ${ }^{2}$ Botanical survey of India, ERC Shillong, Meghalaya-793003, India. Email: ashishprabhugaonkar@yahoo.co.in
}

Pratibha J, Prabhugaonkar A 2016 - Distribution and phylogeny of Mycosisymbrium cirrhosum. Mycosphere 7(1), 44-50, Doi 10.5943/mycosphere/7/1/5

\begin{abstract}
The genus Mycosisymbrium was described in 1994 from dead leaves of Vaccinium macrocarpon and is monotypified by $M$. cirrhosum. There have been no further records of this species. During the study of litter degrading asexual fungi from the Western Ghats of Goa we collected M. cirrhosum from leaf litter of Gnetum ula and successfully obtained a culture of this fungus through single spore isolation. The multi-gene phylogenetic analysis shows that Mycosisymbrium is a well-supported sister genus to Ochroconis and Verruconis in the family Sympoventuriaceae of the order Venturiales.
\end{abstract}

Key words - Asexual morph - Sympoventuriaceae - Venturiales - Western Ghats

\section{Introduction}

It is important to place asexual fungi in families, orders and classes of Ascomycota and Basidiomycota in order to move towards a natural classification. In this way asexual and sexual fungi can be linked and this reduces redundancy resulting from the dual naming system (Hyde et al. 2011; Wijayawardene et al. 2014). Our work on the phylogeny of asexual fungi (Pratibha \& Prabhugaonkar 2015a, 2015b, Pratibha et al. 2014a, 2014b) yielded a rare collection of the monotypic asexual genus Mycosisymbrium, with M. cirrhosum Carris, originally described from dead leaves of Vaccinium macrocarpon from Massachusetts, USA (Carris 1994). The genus is characterized by a discrete aggregates of conidiophores terminating in sterile, filiform appendages and brown, one-septate conidia. There have been no further records of this fungus since it was described. In this study, M. cirrhosum was isolated from leaf litter of Gnetum ula Brongn. from the forests of Valpoi, Goa, India and was subsequently cultured. Single spore cultures readily sporulated. Multi-gene phylogenetic analysis was carried out to confirm the phylogenetic placement of Mycosisymbrium as a well-supported sister genus to Ochroconis and Verruconis in the family Sympoventuriaceae in the order Venturiales.

\section{Materials and methods}

\section{Collection and culturing}

Mycosisymbrium cirrhosum was isolated on leaf litter of Gnetum from the forests of Sattari, Goa, India. Samples were brought to the laboratory in Zip-lock polythene bags and examined under a stereoscope. The fungus was picked up with a sterile needle, mounted in 
lactophenol and observed under a light microscope. The species was isolated in culture from single conidia as described in Chomnunti et al. (2014). The developing colonies, emerged from individual conidium, were aseptically transferred into fresh plates. After confirming the identity of the culture, molecular sequencing was done at Rajiv Gandhi Centre for Biotechnology, Thiruvananthpuram, Kerala, India. Culture is deposited at Microbial type culture collection (MTCC) at Institute of Microbial Technology, Chandigarh, India. The taxonomic record has been deposited in Faces of Fungi (Jayasiri et al. 2015).

\section{DNA isolation and PCR Analysis}

Fresh fungal mycelia $(20 \mathrm{mg})$, scraped from the growing culture incubated at $28^{\circ} \mathrm{C}$ for 7 days. DNA isolation and PCR analysis was done according to Prabhugaonkar \& Bhat (2011). The 5.8S nuclear ribosomal gene with the two flanking internal transcribed spacers (ITS), 18S nrDNA sequence (SSU), 28S nrDNA sequence (LSU) and RNA polymerase second largest subunit (RBP2) genes were amplified and sequenced using the primer pairs ITS-1F + ITS-4R, NS-1F + NS-4R (White et al. 1990), LR5 + LROR (Crous et al. 2009) and FRPB2-5F + FRPB2-7cR respectively. The sequence quality was checked using Sequence ScannerSoftware v1 (Applied Biosystems). Sequence alignment and required editing of the obtained sequences were carried out using Geneious Pro v5.1 (Drummond et al. 2010).

\section{Sequence alignment and phylogenetic analysis}

The sequences were blasted in GenBank with Blastn. ITS, LSU, SSU and RPB2 data sets were analysed. Based on the blasts and available literature (Samerpitak et al. 2014), further related sequences were assembled. The combined data matrix was aligned using MAFFT v.7 (http://mafft.cbrc.jp/alignment/software) and manually adjusted using MEGA 6.06 to allow maximum alignment and maximum sequence similarity. A phylogenetic analysis was conducted using maximum likelihood (ML) in MEGA 6.06 (Kumar et al. 2008) with 1000 bootstrap replicates. The most suitable substitution models for the respective data sets were selected by using MEGA6.06. Tamura Nei model with Gamma distribution was used in analysis. Gaps were treated as a pairwise deletion and trees were viewed with MEGA6.06. All newly generated sequences used in this study are deposited in GenBank.

\section{Results}

\section{Phylogenetic analyses}

Thirty taxa are included in the phylogenetic analysis (Table 1, Fig. 1). Preliminary phylogenetic analysis showed that Mycosisymbrium has affinities with Ochroconis and Verruconis (Sympoventuriaceae, Venturiales, Zhang et al. 2011, Machouart et al. 2014, Samerpitak et al. 2014). A dataset of Sympoventuriaceae and Venturiaceae from the order Venturiales was assembled. Pleospora herbarum (Pleosporales) was selected as the out-group taxon. With multi-gene phylogenetic analysis it is observed that genus forms a well-supported clade within Sympoventuriaceae (Venturiales, Dothideomycetes) with Ochroconis and Verruconis as sister genera, confirming the distinctiveness of the genus (Fig. 1).

\section{Taxonomy}

Mycosisymbrium cirrhosum Carris

Fig. 2

Facesoffungi number: FoF 01834, FOF 01835

Colonies on natural substrate effuse, brown; mycelium immersed. Colonies on MEA woolly, brown, reverse black, margin serrated, attaining a diam. of 1.9-2.2 cm in 10 days. Sexual morph: Undetermined. Asexual morph: Conidiophores macronematous, clustered, discrete, mononematous, branched, light brown, smooth-walled, 30-52 $\times 2-3 \mu \mathrm{m}$, each branch terminating in a filiform appendage. Appendages hyaline, flexuous, 22-35 $\times 1 \mu \mathrm{m}$. Conidiogenous cells mono 


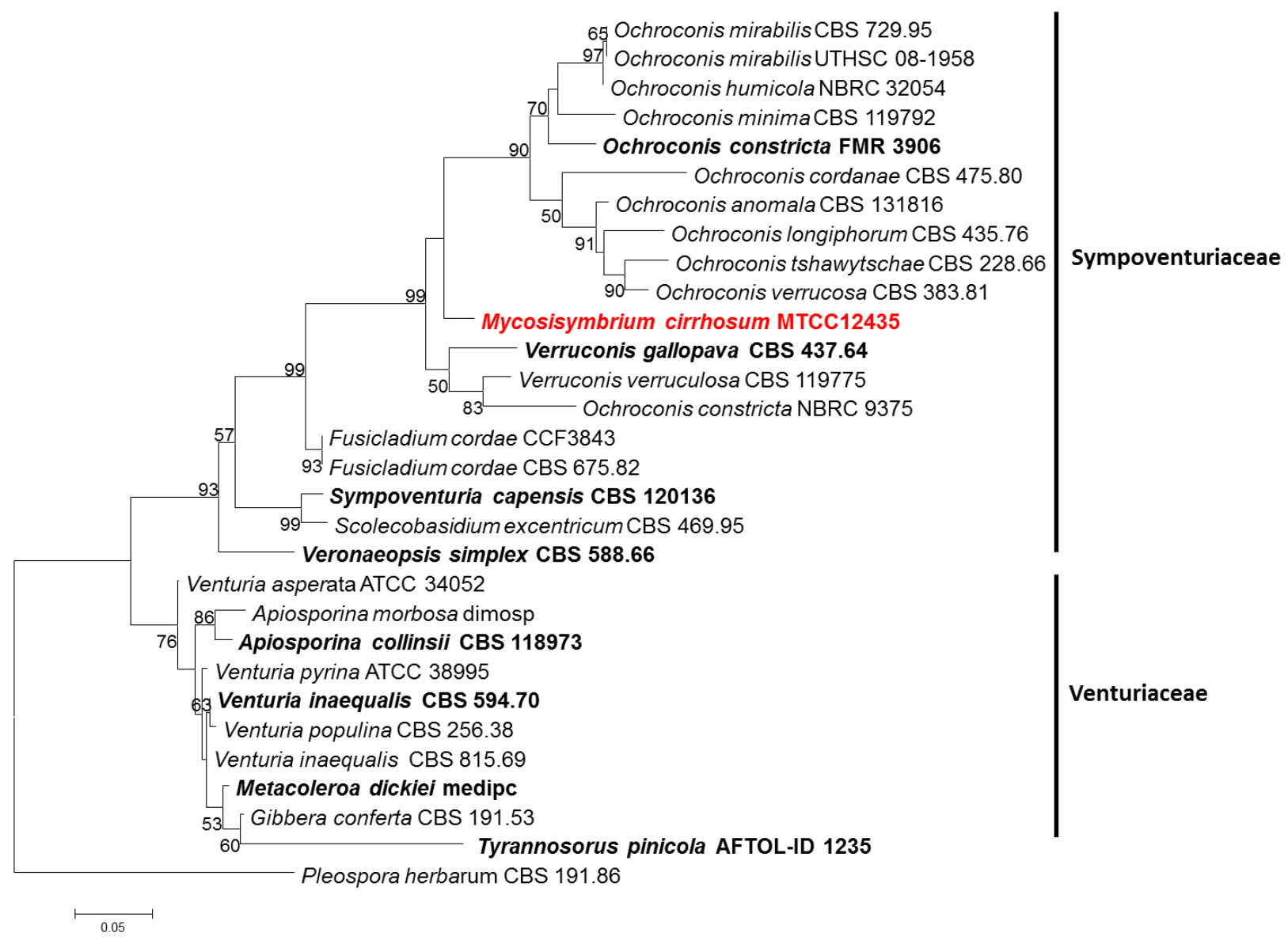

Fig. 1 - Maximum likelihood (ML) tree inferred from SSU, ITS, LSU and RPB2 showing the relationship of Mycosisymbrium cirrhosum with Ochroconis in Sympoventuriaceae (Venturiales). New sequence data is in red. Ex-type strains are in bold.

to polyblastic, light brown, smooth walled, denticulate, 6-10.5 $\times 2-3 \mu \mathrm{m}$. Conidia solitary, oblong, rounded at the apex, brown, smooth-walled, 1-septate, slightly constricted at septum, 7.5$9 \times 2.5-4 \mu \mathrm{m}$.

Material examined - INDIA, Goa, Valpoi, on leaf litter of Gnetum ula (Gnetaceae),26 January, J. Pratibha (Herb. No. VTL-5); living culture. MTCC12435

Notes - The new collection is identical to the original protologue in all morphological characters, except for the size of appendages, conidiogenous cells and conidia, with a maximum variation of only $2 \mu \mathrm{m}$.

\section{Discussion}

This second report of poorly known taxon extends its distribution to Western Ghats, India from its original locality in USA (Carris 1994) with a new host record. This also provides a natural phylogenetic placement for the genus. In this study we show using molecular data that Mycosisymbrium is well-supported sister genus to Ochroconis and Verruconis in the family Sympoventuriaceae, in the order Venturiales (Samerpitak et al. 2014, Machouart et al. 2014, Hyde et al. 2013, Zhang et al. 2011). This relation is further supported by morphological similarity to genus Ochroconis in having two celled spores, slightly constricted at the septa and polyblastic conidiogenous cells. However Mycosisymbrium differs from Ochroconis in having discrete aggregates of conidiophores terminating in sterile, filiform appendages. Ochroconis species are oligotrophic saprobes and some opportunistic species cause infections in vertebrates, its taxonomic status was recently reviewed by Machouart et al. (2014) using multi-gene phylogenetic analysis. 

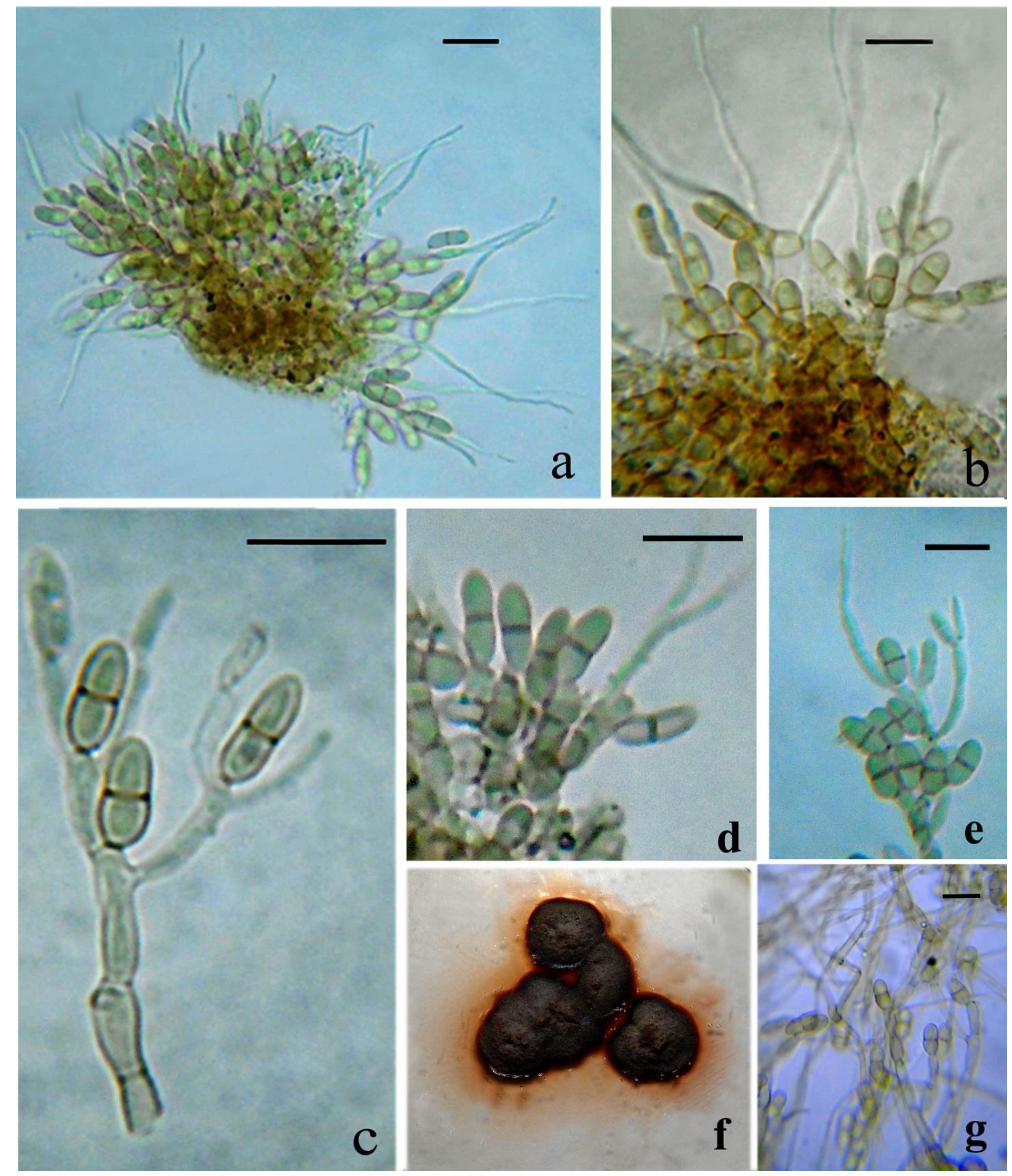

Fig. 2 - Mycosisymbrium cirrhosum.a, Conidiophore aggregates with conidia, b, Filiform appendages terminating from conidiophores. c- e, Conidiogenous cells and conidia. f, Culture. g, Conidiophores in culture. Scale bars $=10 \mu \mathrm{m}$.

The current study did not reveal the sexual morph of Mycosisymbrium. Furthermore, the study strengthens the generic concepts of Mycosisymbrium by providing molecular evidence, in addition to morphological evidence provided by Carris (1994). Index Fungorum/ MycoBank (MB 27274) mentions that Mycosisymbriumis a synonym of Scolecobasidiella, while listing the name Mycosisymbrium cirrhosum as legitimate, hence creating confusion. The current collection supports the distinctiveness of Mycosisymbrium from Scolecobasidiella and other sister genera in Sympoventuriaceae in having mononematous conidiophores, having distinct branching, in producing an aggregation of conidiophores and having each branch terminating in a filiform appendage. 
Table 1 Sequence data used in combined ITS, SSU, LSU and RBP2 analyses. Newly deposited sequences are in bold.

\begin{tabular}{|c|c|c|c|c|c|}
\hline Taxon & Accession no. & ITS & SSU & LSU & RPB2 \\
\hline Apiosporina collinsii & CBS 118973 & -- & GU296135 & GU301798 & GU357778 \\
\hline Apiosporina morbosa & dimosp & -- & EF114718 & EF114694 & -- \\
\hline Fusicladium cordae & CCF3843 & FN549910 & -- & FN377748 & -- \\
\hline Fusicladium cordae & CBS 675.82 & FN549913 & -- & FN398149 & -- \\
\hline Gibbera conferta & CBS 191.53 & -- & GU296150 & GU301814 & GU357758 \\
\hline Metacoleroa dickiei & medipc & -- & EF114719 & EF114695 & -- \\
\hline Mycosisymbrium cirrhosum & MTCC12435 & KR259883 & KR259885 & KR259884 & KR349124 \\
\hline Ochroconis anomala & CBS 131816 & -- & KF156065 & KF156137 & -- \\
\hline Ochroconis constricta & FMR 3906 & LM644509 & -- & LM644552 & -- \\
\hline Ochroconis constricta & NBRC 9375 & DQ307327 & AB564608 & AB564619 & DQ415431 \\
\hline Ochroconis cordanae & CBS 475.80 & KF156022 & KF156058 & KF156122 & -- \\
\hline Ochroconis humicola & NBRC 32054 & -- & AB564607 & AB564618 & AB564629 \\
\hline Ochroconis longiphorum & CBS 435.76 & KF156038 & KF156060 & KF156135 & - \\
\hline Ochroconis minima & CBS 119792 & KF156027 & KF156086 & KF156133 & -- \\
\hline Ochroconis mirabilis & CBS 729.95 & KF156029 & KF156082 & KF156144 & -- \\
\hline Ochroconis mirabilis & UTHSC 08-1958 & LM644517 & -- & LM644561 & -- \\
\hline Ochroconis tshawytschae & CBS 228.66 & KF156016 & KF156064 & KF156128 & -- \\
\hline Ochroconis verrucosa & CBS 383.81 & KF156015 & KF156067 & KF156129 & -- \\
\hline Pleospora herbarum & CBS 191.86 & KC584239 & GU238232 & GU238160 & KC584471 \\
\hline Scolecobasidium excentricum & CBS 469.95 & -- & KF282683 & KF282669 & -- \\
\hline Sympoventuria capensis & CBS 120136 & KF156039 & KF156094 & KF156104 & -- \\
\hline Tyrannosorus pinicola & AFTOL-ID 1235 & -- & DQ471025 & DQ470974 & DQ470928 \\
\hline Venturia asperata & ATCC 34052 & -- & EF114736 & $\mathrm{EF} 114711$ & -- \\
\hline Venturia inaequalis & CBS 594.70 & KF156040 & GU296205 & GU301879 & GU357757 \\
\hline Venturia inaequalis & CBS 815.69 & -- & GU296204 & GU301878 & GU357756 \\
\hline Venturia populina & CBS 256.38 & EU035467 & GU296206 & GU323212 & GU357769 \\
\hline Venturia pyrina & ATCC 38995 & -- & EF114739 & EF114714 & -- \\
\hline Veronaeopsis simplex & CBS 588.66 & KF156041 & KF156095 & KF156103 & -- \\
\hline Verruconis gallopava & CBS 437.64 & HQ667553 & KF156053 & KF156112 & -- \\
\hline Verruconis verruculosa & CBS 119775 & KF156014 & KF156055 & KF156106 & -- \\
\hline
\end{tabular}

\section{Acknowledgements}

Thanks are due to the University Grants Commission, New Delhi, for a postdoctoral research grant support to PJ. We take this opportunity to thank Head of Department of Botany, Goa University and guide Prof. M. K. Janarthanam for supporting this work. AP is thankful to Head, BSI, ERC, Shillong and The Director, Botanical Survey of India for support.

\section{References}

Carris LM. 1994 - Vaccinium Fungi: Mycosisymbrium cirrhosum gen. et sp. nov. Mycologia 86, 131-133. http://dx.doi.org/10.2307/3760728

Chomnunti P, Hongsanan S, Aguirre-Hudson B, Tian Q, Peršoh D, Dhami MK, Hyde KD. 2014 The sooty moulds. Fungal Diversity 66, 1-36

Crous PW, Braun U, Wingfield MJ, Wood AR, Shin HD, Summerell BA, Alfenas AC, Cumagun CJ, Groenewald JZ. 2009 - Phylogeny and taxonomy of obscure genera of microfungi. Persoonia 22, 139-161. http://dx.doi: 10.3767/003158509X461701

Drummond AJ, Ashton B, Buxton S, Cheung M, Cooper A, Heled J, Kearse M, Moir R, Stones Havas S, Sturrock S, Thierer T, Wilson A. 2010 - Geneious v. 5.1, available from 485 http://www.geneious.com.

Hyde KD, McKenzie EHC, KoKo TW. 2011 - Towards incorporating anamorphic fungi in a natural classification - checklist and notes for 2010. Mycosphere 2(1), 1-88.

Hyde KD, Jones EBG, Liu JK, Ariyawansa HA, Boehm E, Boonmee S, Braun U, Chomnunt P, Crous PW, Dai DQ, Diederich P, Dissanayake A, Doilom M, Doveri F, Hongsanan S, 
Jayawardena R, Lawrey JD, Li YM, Liu YX, Lücking R, Monkai J, Muggia L, Nelsen MP, Pang KL, Phookamsak R, Senanayake I, Shearer CA, Suetrong S, Tanaka K, Thambugala KM, Wijayawardene NN, Wikee S, Wu HX, Zhang Y, Hudson BA, Alias SA, Aptroot A, Bahkali AH, Bezerra JL, Bhat JD, Camporesi E, Chukeatirote E, Gueidan C, Hawksworth DL, Hirayama K, De Hoog S, Kang JC, Knudsen K, Li WJ, Li X, Liu ZY, Mapook A, McKenzie EHC, Miller AN, Mortimer PE, Phillips AJL, Raja HA, Scheuer C, Schumm F, Taylor JE, Tian Q, Tibpromma S, Wanasinghe DN, Wang Y, Xu J, Yan J, Yacharoen S, Zhang M. 2013 - Families of Dothideomycetes. Fungal Diversity 63, 1-313. http://dx.doi.org/10.1007/s13225-013-0263-4

Jayasiri SC, Hyde KD, Abd-Elsalam KA, Abdel-Wahab MA, Ariyawansa HA, Bhat J, Buyck B, Dai YC, Ertz D, Hidayat I, Jeewon R, Jones EBG, Karunarathna SC, Kirk P, Lei C, Liu JK, Maharachchikumbura SSN, McKenzie E, Ghobad-Nejhad M, Nilsson H, Pang KL, Phookamsak R, Rollins AW, Romero AI, Stephenson S, Suetrong S, Tsui CKM, Vizzini A, Wen TC, De Silva NI, Promputtha I, Kang JC 2015 - The faces of fungi database: fungal names linked with morphology, molecular and human attributes. Fungal Diversity 74, 3-18. http://dx.doi.org/10.1007/s13225-015-0351-8

Kumar S, Nei M, Dudley J, Tamura K. 2008 - MEGA: a biologist-centric software for evolutionary analysis of DNA and protein sequences. Briefings in Bioinformatics 9, 299306.

Machouart M, Samerpitak K, de-Hoog GS, Gueidan C.2014 - A multigene phylogeny reveals that Ochroconis belongs to the family Sympoventuriaceae (Venturiales, Dothideomycetes). Fungal Diversity 65, 77-88. http://dx.doi.org/10.1007/s13225-013-0252-7

Prabhugaonkar A, Bhat DJ. 2011 - New record of Megacapitula villosa and Paradictyoarthrinium diffractum from India. Mycosphere 2(4), 463-467

Pratibha J, Prabhugaonkar A. 2015a. - Multi-gene phylogeny of Pithomyces with the sexual morph of P. flavus Berk. \& Broome. Phytotaxa 218 (1), 84-90.

http://dx.doi.org/10.11646/phytotaxa.218.1.7

Pratibha J, Prabhugaonkar A. 2015b - New record of Thysanorea papuana from India. Mycosphere 6(4), 463-467. http://dx.doi.org/ Doi 10.5943/mycosphere/6/4/9

Pratibha J, Mel'nikVA, Bhat DJ, NguyenHDT, SeifertKA.2014a - Taxonomy and phylogeny of Pseudogliophragma indica and its synonym Ramaraomyces corticola, a synnematous hyphomycete from south east Asia. Mycoscience 56 (4), 387-395 http://dx.doi.org/10.1016/j.myc.2014.12.002

Pratibha J, Prabhugaonkar A, Bhat DJ, Hyde KD. 2014b - Phylogenetic placement of Bahusandhika, Cancellidium and Pseudoepicoccum (asexual Ascomycota). Phytotaxa. 176 (1): 68-80. http://dx.doi.org/10.11646/phytotaxa.176.1.9

Samerpitak K, Van der Linde E, Choi HJ, Gerrits van den Ende AHG, Machouart M, Gueidan C, de Hoog GS. 2014-Taxonomy of Ochroconis, genus including opportunistic pathogens on humans and animals. Fungal Diversity 65, 89-126. http://dx.doi.org10.1007/s13225-0130253-6

White TJ, Bruns T, Lee S, Taylor J. 1990 - Amplification and direct sequencing of fungal ribosomal RNA genes for phylogenetics. In: Innis MA, Gelfand DH, Sninsky JJ, White TJ, (Eds.) PCR protocols: a guide to methods and applications. Academic Press, New York, USA: $315-322$

Wijayawardene NN, Crous PW, Kirk PM, Hawksworth DL, Boonmee S, Braun U, Dai DQ, D ' souza MJ, Diederich P, Dissanayake A, Doilom M, Hongsanan S, Jones EBG, Groenewald JZ, Jayawardena R, Lawrey JD, Liu J-K, Luecking R, Madrid H, Manamgoda DS, Muggia L, Nelsen MP, Phookamsak R, Suetrong S, Tanaka K, Thambugala KM, Wanasinghe DN, Wikee S, Zhang Y, Aptroot A, Ariyawansa HA, Bahkali AH, Bhat DJ, Gueidan C, Chomnunti P, De Hoog GS, Knudsen K, Li W-J, McKenzie EHC, Miller AN, Phillips AJL, Piatek M, Raja HA, Shivas RS, Slippers B, Taylor JE, Tian Q, Wang Y, Woudenberg JHC, Cai L, Jaklitsch WM, Hyde KD. 2014 - Naming and outline of Dothideomycetes- 2014 
including proposals for the protection or suppression of generic names. Fungal Diversity 69:1-55

Zhang Y, Crous PW, Schoch CL, Bahkali AH, Guo LD, Hyde KD. 2011 - A molecular, morphological and ecological re-appraisal of Venturiales-a new order of Dothideomycetes. Fungal Diversity 51(1), 249-277. http://dx.doi.org/10.1007/s13225-0110141-x 